\title{
Standardization of Propagation Techniques in Manila Tamarind (Pithecellobium dulce (Roxb.) Benth.) var. PKM 1
}

\author{
R. Keerthika ${ }^{1}$, J. Rajangam ${ }^{1 *}$, T. Arumugam ${ }^{1}$ and K. Venkatesan ${ }^{2}$ \\ ${ }^{1}$ Department of Fruit Science, ${ }^{2}$ Department of Floriculture \& Landscape Architecture, \\ Horticultural College and Research Institute, Tamil Nadu Agricultural University, \\ Periyakulam, Theni District, Tamil Nadu, India \\ *Corresponding author
}

\section{Keywords}

Propagation, Softwood grafting, Survival, Success, Hardwood, Interaction

\section{Article Info}

Accepted: 04 October 2020 Available Online: 10 November 2020

\section{A B S T R A C T}

The present investigation on the standardization of propagation techniques in Manila tamarind (Pithecellobium dulce (Roxb.) Benth.) was conducted at the Department of Fruit Science, Horticultural College and Research Institute, Periyakulam. This study includes three different propagation methods, i.e. hardwood cuttings, softwood grafting and patch budding at six different time of propagation, viz., $15^{\text {th }}$ July, $15^{\text {th }}$ August, $15^{\text {th }}$ September, $15^{\text {th }}$ October, $15^{\text {th }}$ November and $15^{\text {th }}$ Decemberduring the year 2019-2020. The results of this present study generally indicated that both the main and interaction effects of propagation methods with time of propagation had a significant influence on number of days taken to first sprouting, number of leaves and shoots/plant, fresh and dry weight of leaves, leaf area $\left(\mathrm{cm}^{2}\right)$, chlorophyll content $(\mathrm{mg} / \mathrm{g})$, phenol content $(\mathrm{mg} / \mathrm{g})$, success and survival percentage of manila tamarind under mist chamber condition. The experimental results revealed that among the three propagation methods evaluated, softwood grafting performed well on $15^{\text {th }}$ July which recorded the highest success percentage $(97.33 \%)$, survival percentage $(92.99 \%)$ after 90 days of propagation and also observed maximum number of leaves (178.46) and shoots per plant (13.17). In addition, chlorophyll content was higher on $15^{\text {th }}$ August of softwood grafting $(0.80 \mathrm{mg} / \mathrm{g})$ while the hardwood cuttings planted on $15^{\text {th }}$ July was registered the earlier sprouting (6.56 days).

\section{Introduction}

Pithecellobium dulce (Roxb.) Benth. belongs to the family Fabaceae, native to Mexico, South America and Central America. It is common in India, Malaysia and Thailand (Lal and Nath, 2017). The generic name derived from the Greek for "ape's earring" referring to the coiled pods; the Latin species name, meaning "sweet", describes the edible seed pulp (Little, 1983). Manila tamarind is one of the major underutilized fruit crops which may be an important fruit for the future due to its high medicinal value, high production per unit area and suitable for wasteland cultivation. The fruit pulp is taken orally to stop blood flow in case of haemoptysis, seeds when grounds are used to cleanse ulcers and also numerous studies have been performed on anti-oxidant, anti-inflammatory, anti-diabetic, 
anti-cancerous properties. However, it is best known as a good hedging plant and is widely used as such in southern India, especially in Tamil Nadu.

Pithecellobium dulce has long been raised by seeds, results in long gestation period and lack of improved cultivars despite its high potential as a dry land horticultural fruit crop and its multifarious uses. There is a greater demand for true to type propagules, in order to optimize the production of quality fruits and advance commencement of flowers. True to type seedlings have the uniform characters as that of mother plants, it fulfils the farmer's demand. Any propagation method which can be successfully adopted will vary from region to region due to environmental factors such as temperature, relative humidity, rainfall etc., Manila tamarind is the emerging fruit crop in the market and the research work on vegetative propagation of Manila tamarind is rather scanty and sporadic. Therefore, the present study was conducted to standardize the method and time of propagation in Manila tamarind.

\section{Materials and Methods}

The studies on standardization of propagation technique on Manila tamarind plants were carried out during 2019-2020 at the Department of Fruit Science, Horticultural College and Research Institute, Tamil Nadu Agricultural University, Periyakulam. The experiment was laid out in Factorial Completely Randomized Design (FCRD) with two factors and three replications. The experiment is situated in the tropical Zones at latitude of $10.1283^{\circ} \mathrm{N}$ and longitude of $77.5998^{\circ} \mathrm{E}$. The temperature ranges from $25^{\circ} \mathrm{C}$ to $38^{\circ} \mathrm{C}$ and relative humidity was maintained between $80-90 \%$. hardwood Cuttings, softwood Grafting and patch budding were tried for six months viz., $15^{\text {th }}$ June, $15^{\text {th }}$ July, $15^{\text {th }}$ August, $15^{\text {th }}$ September, $15^{\text {th }}$ October, $15^{\text {th }}$ November and $15^{\text {th }}$ December.

Seeds were collected from local variety and the rootstocks were raised in polythene bags. Polythene bags of thickness 5"-7" (250 guage) were used to raise the rootstocks. The pot mixture of red earth, sand and well decomposed FYM (1:1:1) was prepared and filled in the polythene bag, then the healthy seeds were sowed. Scions of PKM 1 manila tamarind were used to graft the rootstocks in different months. The prepared grafts were covered from top by polythene cap and this cap was retained on the graft till sprouting was observed on the graft. The various biometrical observations were recorded on five randomly selected plants of each replication to assess the vegetative characters, i.e. number of days taken to sprouting, number of leaves/plant, success \& survival percentage $(\%)$.The observations on average leaf fresh weight $(\mathrm{g})$, average leaf dry weight (g) and chlorophyll content $(\mathrm{mg} / \mathrm{g})$ were recorded under laboratory condition.

The data on the success percentage and survival percentage was recorded after 90 days of planting the cutting/grafting/budding by taking the ratio multiplied by 100 . The data regarding the number of days taken to sprouting was calculated by observing the plants on alternate days from the days of planting and their mean values was used to calculate the number of days required for first sprout. The average fresh weight of the leaves was measured from the weighing balance and dry weight of the leaves was measured after drying in oven for $25 \mathrm{~min}$ at $73^{\circ} \mathrm{C}$ from the weighing balance. The chlorophyll percentage was calculated after 90 days of propagation. The number of new leaves/plant recorded at 30, 60, 90 days after propagating through cuttings/ grafting/budding. Then the data were statistically analysed as per the method suggested by Panse and Sukhtame (2000). 


\section{Results and Discussion}

\section{Effect of time and method of propagation on number of days taken for sprouting}

The results revealed that there was a significant effect of time and propagation on days taken for first sprouting in Manila tamarind. It is evident from data (Table 1) that minimum time required for bud sprouting was observed when propagation was performed on $15^{\text {th }}$ July (10.31 days) followed by $15^{\text {th }}$ August (11.14 days) and $15^{\text {th }}$ December (11.84 days). Among the treatments it was the hardwood cuttings (8.25 days) which sprout earliest followed by softwood grafting (8.50 days) and patch budding (19.31 days). The interaction effect of methods and time of propagation indicates the earliest sprouting was observed when hardwood cuttings performed on $15^{\text {th }}$ July (6.56 days). The maximum time taken for bud sprouting was observed in the method of patch budding propagated on $15^{\text {th }}$ November (22.25 days). The various interactions between time and techniques of propagation on days taken for bud sprouting were also found to be significant.

\section{Effect of method and time of propagation on number of leaves/plant}

From the data presented in the table 2 , it is evident the effect of time and technique of propagation significantly influences the number of leaves/plant (Table 2). The maximum number of leaves were observed in the plants of propagation performed on $15^{\text {th }}$ July (133.93) followed by $15^{\text {th }}$ August (126.95) and $15^{\text {th }}$ December (118.26) and the minimum was on $15^{\text {th }}$ September (82.46) and $15^{\text {th }}$ October (111.52) propagated plants. Among the methods of propagation, softwood grafts recorded the maximum number of leaves/plants (155.90) and the minimum number of leaves was recorded in patch budding (52.12). The interaction effect of method and time of propagation indicates that the highest number of leaves was observed when softwood grafting done on $15^{\text {th }}$ July (178.46) which is on par with $15^{\text {th }}$ August (172.83) followed by $15^{\text {th }}$ December (160.32) plants. The various interactions between time and techniques of propagation on number of leaves/plant was also found significant.

\section{Effect of method and time of propagation on number of shoots/plant}

It was determined that the propagation method, time of propagation and methods $x$ propagation times had a significant effect on number of shoots/plant. The data regarding number of shoots/plant is presented in the table 3 shows that plants propagated on1 $5^{\text {th }}$ July (7.34) recorded maximum number of shoots on 90 DAP followed by $15^{\text {th }}$ August (6.33) and $15^{\text {th }}$ December (5.61), it found to be least in the month of September (3.70)and October (4.66). Among the treatments, softwood grafting recorded the maximum number of shoots/plant (8.91). The interaction effect of method and time of propagation indicates that the highest number of shoots/plant was noticed in softwood grafting done on $15^{\text {th }}$ July (13.17).

\section{Effect of method and time of propagation on success percentage $(\%)$}

Different time and methods of propagation had significant influence on success percentage in manila tamarind. Data presented in the table 4 indicates that among different time and methods of propagation highest per cent success was recorded in softwood grafting $(92.50 \%)$. Percentage of success was recorded maximum on $15^{\text {th }}$ July $(85.00 \%)$ propagated plants. Interaction of time and methods of propagation also had a significant effect on success percentage. After 90 days of propagation, the highest success 
percentage was recorded in softwood grafting on $15^{\text {th }}$ July $(97.33 \%)$ grafted plants followed by $15^{\text {th }}$ August $(95.33 \%)$ of same method and hardwood cuttings performed on $15^{\text {th }}$ July $(91.00 \%)$. The minimum or below average percentage was recorded in the method of patch budding during the month of September $(51.00 \%)$.

Effect of method and time of propagation on survival percentage $(\%)$

Analysis of data presented in the table 5 indicated that among different method and time of propagation, maximum survival percentage was recorded in softwood grafting $(86.21 \%)$. The effect of time of propagation was also significant with respect to survival percentage, the maximum survival percentage was observed in $15^{\text {th }}$ July $(80.57 \%)$ propagated plants followed by $15^{\text {th }}$ August $(77.21 \%)$ and $15^{\text {th }}$ December $(75.25 \%)$. The survival percentage of manila tamarind was also influenced by the interaction of time and methods of propagation where maximum in softwood grafting during $15^{\text {th }}$ July $(92.99 \%)$ propagated grafts which is on par with $15^{\text {th }}$ August $(91.43 \%)$ and $15^{\text {th }}$ December $(88.34 \%)$ grafted plants.

\section{Effect of method and time of propagation on chlorophyll content of leaves (mg/g)}

Chlorophyll content was influenced by different time and method of propagation (Table 6) showed significant differences after 90 days of propagation. Among different methods of propagation, maximum chlorophyll content was recorded in the method of softwood grafting $(0.70 \mathrm{mg} / \mathrm{g})$. Among different time of propagation, maximum chlorophyll content was recorded in $15^{\text {th }}$ August $(0.75 \mathrm{mg} / \mathrm{g})$ propagated plants. It is evident from the data (Table 6) that interaction of methods and time of propagation had significant effect with respect to chlorophyll content. The maximum chlorophyll content was observed in the method of softwood grafted plants on $15^{\text {th }}$ August $(0.80 \mathrm{mg} / \mathrm{g})$ propagated grafts.

Table.1 Effect of methods and time of propagation on number of days taken to sprouting in manila tamarind at $90 \mathrm{DAP}$

\begin{tabular}{|c|c|c|c|c|c|c|c|}
\hline & \multicolumn{6}{|c|}{ Time of propagation } & \multirow[b]{2}{*}{ Mean } \\
\hline $\begin{array}{l}\text { Method of } \\
\text { propagation }\end{array}$ & $\begin{array}{l}15^{\text {th }} \\
\text { July }\end{array}$ & $\begin{array}{c}15^{\text {th }} \\
\text { August }\end{array}$ & $\begin{array}{c}15^{\text {th }} \\
\text { September }\end{array}$ & $\begin{array}{c}15^{\text {th }} \\
\text { October }\end{array}$ & $\begin{array}{c}15^{\text {th }} \\
\text { November }\end{array}$ & $\begin{array}{c}15^{\text {th }} \\
\text { December }\end{array}$ & \\
\hline $\begin{array}{l}\text { Hardwood } \\
\text { cutting }\end{array}$ & 6.56 & 7.05 & 8.49 & 9.96 & 8.54 & 8.92 & 8.25 \\
\hline $\begin{array}{c}\text { Softwood } \\
\text { grafting }\end{array}$ & 7.34 & 8.61 & 9.76 & 7.77 & 8.83 & 8.71 & 8.50 \\
\hline $\begin{array}{c}\text { Patch } \\
\text { budding }\end{array}$ & 17.03 & 17.76 & 20.60 & 20.36 & 22.25 & 17.90 & 19.31 \\
\hline \multirow[t]{2}{*}{ Mean } & 10.31 & 11.14 & 12.95 & 12.70 & 13.21 & 11.84 & \\
\hline & \multicolumn{2}{|c|}{ Methods } & \multicolumn{2}{|c|}{ Time } & \multicolumn{3}{|c|}{ Interaction $(\mathbf{M} \times \mathbf{T})$} \\
\hline SE(d) & \multicolumn{2}{|c|}{0.38} & \multicolumn{2}{|c|}{0.54} & \multicolumn{3}{|c|}{0.94} \\
\hline $\mathrm{CD}(\mathrm{p}=0.05)$ & \multicolumn{2}{|c|}{0.78} & \multicolumn{2}{|c|}{1.10} & \multicolumn{3}{|c|}{1.91} \\
\hline
\end{tabular}


Table.2 Effect of methods and time of propagation on number of leaves/ plant in manila tamarind at 90 DAP

\begin{tabular}{|c|c|c|c|c|c|c|c|}
\hline & \multicolumn{6}{|c|}{ Time of propagation } & \multirow[b]{2}{*}{ Mean } \\
\hline $\begin{array}{l}\text { Method of } \\
\text { propagation }\end{array}$ & $\begin{array}{l}15^{\text {th }} \\
\text { July }\end{array}$ & $\begin{array}{c}15^{\text {th }} \\
\text { August }\end{array}$ & $\begin{array}{c}15^{\text {th }} \\
\text { September }\end{array}$ & $\begin{array}{c}15^{\text {th }} \\
\text { October }\end{array}$ & $\begin{array}{c}15^{\text {th }} \\
\text { November }\end{array}$ & $\begin{array}{c}15^{\text {th }} \\
\text { December }\end{array}$ & \\
\hline Hardwood cutting & 150.69 & 145.46 & 90.08 & 132.87 & 130.96 & 140.23 & 131.71 \\
\hline Softwood grafting & 178.46 & 172.83 & 125.20 & 153.28 & 145.32 & 160.32 & 155.90 \\
\hline Patch budding & 72.65 & 62.56 & 32.11 & 48.42 & 42.76 & 54.22 & 52.12 \\
\hline \multirow[t]{2}{*}{ Mean } & 133.93 & 126.95 & 82.46 & 111.52 & 106.35 & 118.26 & \\
\hline & \multicolumn{2}{|c|}{ Methods } & \multicolumn{2}{|c|}{ Time } & \multicolumn{3}{|c|}{ Interaction $(\mathbf{M} \times \mathbf{T})$} \\
\hline SE(d) & \multicolumn{2}{|c|}{1.78} & \multicolumn{2}{|c|}{2.52} & \multicolumn{3}{|c|}{4.36} \\
\hline $\mathrm{CD}(\mathrm{p}=\mathbf{0 . 0 5})$ & \multicolumn{2}{|c|}{3.63} & \multicolumn{2}{|c|}{5.13} & \multicolumn{3}{|c|}{8.89} \\
\hline
\end{tabular}

Table.3 Effect of methods and time of propagation on number of shoots/ plant in manila tamarind at 90 DAP

\begin{tabular}{|c|c|c|c|c|c|c|c|}
\hline & \multicolumn{6}{|c|}{ Time of propagation } & \multirow[b]{2}{*}{ Mean } \\
\hline $\begin{array}{l}\text { Method of } \\
\text { propagation }\end{array}$ & $\begin{array}{l}15^{\text {th }} \\
\text { July }\end{array}$ & $\begin{array}{c}15^{\text {th }} \\
\text { August }\end{array}$ & $\begin{array}{c}15^{\text {th }} \\
\text { September }\end{array}$ & $\begin{array}{c}15^{\text {th }} \\
\text { October }\end{array}$ & $\begin{array}{c}15^{\text {th }} \\
\text { November }\end{array}$ & $\begin{array}{c}15^{\text {th }} \\
\text { December }\end{array}$ & \\
\hline Hardwood cutting & 7.87 & 6.84 & 4.30 & 6.20 & 5.82 & 6.77 & 6.30 \\
\hline Softwood grafting & 13.17 & 11.15 & 5.80 & 6.78 & 7.50 & 9.06 & 8.91 \\
\hline Patch budding & 1.00 & 1.00 & 1.00 & 1.00 & 1.00 & 1.00 & 1.00 \\
\hline \multirow[t]{2}{*}{ Mean } & 7.34 & 6.33 & 3.70 & 4.66 & 4.77 & 5.61 & \\
\hline & \multicolumn{2}{|c|}{ Methods } & \multicolumn{2}{|c|}{ Time } & \multicolumn{3}{|c|}{ Interaction $(\mathbf{M} \times \mathbf{T})$} \\
\hline SE(d) & \multicolumn{2}{|c|}{0.16} & \multicolumn{2}{|c|}{0.22} & \multicolumn{3}{|c|}{0.39} \\
\hline $\mathrm{CD}(\mathrm{p}=0.05)$ & \multicolumn{2}{|c|}{0.32} & \multicolumn{2}{|c|}{0.46} & \multicolumn{3}{|c|}{0.80} \\
\hline
\end{tabular}

Table.4 Effect of methods and time of propagation on success percentage (\%) in manila tamarind at 90 DAP

\begin{tabular}{|c|c|c|c|c|c|c|c|}
\hline & \multicolumn{6}{|c|}{ Time of propagation } & \multirow[b]{2}{*}{ Mean } \\
\hline $\begin{array}{l}\text { Method of } \\
\text { propagation }\end{array}$ & $\begin{array}{l}15^{\text {th }} \\
\text { July }\end{array}$ & $\begin{array}{c}15^{\text {th }} \\
\text { August }\end{array}$ & $\begin{array}{c}15^{\text {th }} \\
\text { September }\end{array}$ & $\begin{array}{c}15^{\text {th }} \\
\text { October }\end{array}$ & $\begin{array}{c}15^{\text {th }} \\
\text { November }\end{array}$ & $\begin{array}{c}15^{\text {th }} \\
\text { December }\end{array}$ & \\
\hline $\begin{array}{l}\text { Hardwood } \\
\text { cutting }\end{array}$ & 91.00 & 87.33 & 70.00 & 71.33 & 80.66 & 87.00 & 81.22 \\
\hline $\begin{array}{c}\text { Softwood } \\
\text { grafting }\end{array}$ & 97.33 & 95.33 & 87.33 & 91.66 & 89.00 & 94.33 & 92.50 \\
\hline Patch budding & 68.66 & 65.33 & 51.00 & 61.33 & 57.66 & 63.33 & 61.22 \\
\hline \multirow[t]{2}{*}{ Mean } & 85.00 & 81.88 & 66.44 & 71.22 & 69.77 & 79.11 & \\
\hline & \multicolumn{2}{|c|}{ Methods } & \multicolumn{2}{|c|}{ Time } & \multicolumn{3}{|c|}{ Interaction $(\mathbf{M} \times \mathbf{T})$} \\
\hline SE(d) & \multicolumn{2}{|c|}{1.00} & \multirow{2}{*}{\multicolumn{2}{|c|}{$\begin{array}{l}1.41 \\
2.88\end{array}$}} & \multicolumn{3}{|c|}{2.45} \\
\hline $\mathrm{CD}(\mathrm{p}=0.05)$ & \multicolumn{2}{|c|}{2.03} & & & \multicolumn{3}{|c|}{4.99} \\
\hline
\end{tabular}


Table.5 Effect of methods and time of propagation on survival percentage (\%) in manila tamarind at 90 DAP

\begin{tabular}{|c|c|c|c|c|c|c|c|}
\hline & \multicolumn{6}{|c|}{ Time of propagation } & \multirow[b]{2}{*}{ Mean } \\
\hline $\begin{array}{l}\text { Method of } \\
\text { propagation }\end{array}$ & $\begin{array}{l}15^{\text {th }} \\
\text { July }\end{array}$ & $\begin{array}{c}15^{\text {th }} \\
\text { August }\end{array}$ & $\begin{array}{c}15^{\text {th }} \\
\text { September }\end{array}$ & $\begin{array}{c}15^{\text {th }} \\
\text { October }\end{array}$ & $\begin{array}{c}15^{\text {th }} \\
\text { November }\end{array}$ & $\begin{array}{c}15^{\text {th }} \\
\text { December }\end{array}$ & \\
\hline Hardwood cutting & 87.48 & 82.72 & 64.37 & 66.32 & 77.15 & 81.05 & 76.51 \\
\hline Softwood grafting & 92.99 & 91.43 & 78.00 & 83.87 & 82.64 & 88.34 & 86.21 \\
\hline Patch budding & 61.24 & 57.47 & 43.31 & 53.72 & 50.68 & 56.36 & 53.80 \\
\hline \multirow[t]{2}{*}{ Mean } & 80.57 & 77.21 & 61.89 & 67.97 & 70.16 & 75.25 & \\
\hline & \multicolumn{2}{|c|}{ Methods } & \multicolumn{2}{|c|}{ Time } & \multicolumn{3}{|c|}{ Interaction $(\mathbf{M} \times \mathbf{T})$} \\
\hline SE(d) & \multicolumn{2}{|c|}{1.13} & \multicolumn{2}{|c|}{1.61} & \multicolumn{3}{|c|}{2.79} \\
\hline $\mathrm{CD}(\mathrm{p}=0.05)$ & \multicolumn{2}{|c|}{2.32} & \multicolumn{2}{|c|}{3.28} & \multicolumn{3}{|c|}{5.68} \\
\hline
\end{tabular}

Table.6 Effect of methods and time of propagation on chlorophyll content $(\mathrm{mg} / \mathrm{g})$ in manila tamarind at 90 DAP

\begin{tabular}{|c|c|c|c|c|c|c|c|}
\hline & \multicolumn{6}{|c|}{ Time of propagation } & \multirow[b]{2}{*}{ Mean } \\
\hline $\begin{array}{l}\text { Method of } \\
\text { propagation }\end{array}$ & $\begin{array}{l}15^{\text {th }} \\
\text { July }\end{array}$ & $\begin{array}{c}15^{\text {th }} \\
\text { August }\end{array}$ & $\begin{array}{c}15^{\text {th }} \\
\text { September }\end{array}$ & $\begin{array}{c}15^{\text {th }} \\
\text { October }\end{array}$ & $\begin{array}{c}15^{\text {th }} \\
\text { November }\end{array}$ & $\begin{array}{c}15^{\text {th }} \\
\text { December }\end{array}$ & \\
\hline Hardwood cutting & 0.72 & 0.74 & 0.59 & 0.63 & 0.68 & 0.71 & 0.68 \\
\hline Softwood grafting & 0.75 & 0.80 & 0.58 & 0.64 & 0.70 & 0.73 & 0.70 \\
\hline Patch budding & 0.68 & 0.70 & 0.58 & 0.60 & 0.62 & 0.65 & 0.64 \\
\hline \multirow[t]{2}{*}{ Mean } & 0.72 & 0.75 & 0.58 & 0.62 & 0.66 & 0.70 & \\
\hline & \multicolumn{2}{|c|}{ Methods } & \multicolumn{2}{|c|}{ Time } & \multicolumn{3}{|c|}{ Interaction $(\mathbf{M} \times \mathbf{T})$} \\
\hline SE(d) & \multicolumn{2}{|c|}{0.007} & \multicolumn{2}{|c|}{0.009} & \multicolumn{3}{|c|}{0.016} \\
\hline $\mathrm{CD}(\mathrm{p}=\mathbf{0 . 0 5})$ & \multicolumn{2}{|c|}{0.013} & \multicolumn{2}{|c|}{0.019} & \multicolumn{3}{|c|}{0.033} \\
\hline
\end{tabular}

Effect of time and method of propagation on number of days taken for sprouting

The influence of time and method of grafting were examined under the present investigation. It was observed that among the different months and methods of propagation, the hardwood cuttings made on $15^{\text {th }}$ July $(6.56$ days) took minimum time for initial sprouting closely followed by grafting performed on $15^{\text {th }}$ August (7.05 days) and softwood grafting of $15^{\text {th }}$ July ( 7.34 days). The findings of this investigation are in accordance with the findings obtained by Usare (2016) who observed earliest sprouting when propagation was done during wet season (July-August). Earlier sprouting of hardwood cuttings might be due to there is no bud union as in softwood grafting and patch budding and also it is due to preservation of more food materials in cotyledon and actively growing stage of rootstock that enhance union in grafting. These results were agreement with the findings of Jose and Valasalakumari (1991) and Dhar (1998). The results are in accordance with Rymbai and Reddy (2010) in Guava, steady increase in relative humidity from June to August with temperature approaching down from high temperature of summer to moderate temperature of summer to moderate temperature of rainy and autumn season made the conditions congenial for growth and development of plant in the month of August. 
Effect of method and time of propagation on number of leaves/plant and number of shoots/plant

Among different methods of propagation maximum number of leaves and number of shoots/plant was found in softwood grafting on $15^{\text {th }}$ July (178.46\& 13.17) which is followed by $15^{\text {th }}$ August (172.83\& 11.15) and found minimum in $15^{\text {th }}$ September of patch budding (32.11\& 1.00). The maximum number of shoots and number of leaves in softwood grafting is due to the presence of 34 buds on scio wood instead of single bud on patch used for patch budding. Visen and Singh (2010) also reported that number of bud sticks on scion stick 3-4 buds was all direction ideal for grafting. Finding showing maximum number of shoots and leaves on $15^{\text {th }}$ August are similar with the results of Gurjar and Rajesh (2012) in Aonla, where they confirmed that during rainy season well matured rootstock favoured with high atmospheric Humidity along with fairly high temperature, is found congenial for rapid callus production that ensures formation of an early and strong union between stock and scion. These results are in consistence with Reddy et al., (2014) in mango in which they noticed softwood grafting was best method of propagation in respect of maximum number of leaves and this must be due to better healing process during these months. Similar results were obtained by Nachegowda and Vasanth (1996) in sapota, Rani et al., (2015) in Guava and Karna et al., (2017) in Mango.

\section{Effect of method and time of propagation on success percentage $(\%)$}

The data revealed that highest mean success was recorded in softwood grafting $(92.50 \%)$ which was higher than the other methods viz, hardwood cuttings $(81.22 \%)$ and patch budding $(61.22 \%)$. Among the different months of grafting, the highest mean success was recorded on $15^{\text {th }}$ July $(85.00 \%)$. This was closely followed by $15^{\text {th }}$ August $(81.88 \%$ ) propagated plants using hardwood cuttings. The interaction between time and method of propagation showed maximum success on $15^{\text {th }}$ July in the method of softwood grafting (97.33\%). This might be attributed to the reason that July month grafting coincided with prevalence of high humidity and slightly elevated temperatures. The temperature and relative humidity activate the cambium cells during monsoon. The new callus tissue arising out of the cambial region is composed of thin walled turgid cells which can easily desiccate and die off and relative humidity can protect such cells in the cambial region of the graft union (Hartman and Kester, 1979). Similar findings were suggested by Manga et al., (2017) in Guava, Sanjay et al., (1996)and Ullah et al., (2017) in Mango, Angadi and Rajeshwari (2012) in jamun, Madalageri et al., (1990) in sapota, Chovatia et al., (2000) in Jamun and Kaur \& Kaur (2019) in Mango.

In the present study significantly reduced graft success was noticed in the month of September, inspite of prevalence of favourable climatic conditions. This might be attributed to the complex relation between the shoots and their interaction with environmental condition. This was aggravated due to inadequate rainfall received during the month of September. Similar findings have been documented in other crops like Sapota (Pampana and Sulikeri, 2000) and cashewnut (Swami et al, 1990).

\section{Effect of method and time of propagation on survival percentage $(\%)$}

The graft survival percentage after 90 DAP showed significant differences among the months of propagation. Significantly, high survival percentage was registered in softwood grafts prepared on $15^{\text {th }}$ July ( 92.99 $\%), 15^{\text {th }}$ August $(91.43 \%)$ and on $15^{\text {th }}$ 
December $(88.34 \%)$ followed by Hardwood cutting of $15^{\text {th }}$ July $(87.48 \%)$. The Maximum graft survival happens because the grafting time might have favoured the information of new cambial layer in the cambium bridge at the right time and laying down secondary xylem towards the inside and phloem towards the outside in deriving vascular connection before the new bud and leaves formation ensured highest survival percentage in the present study. Then the interaction between the method and time of grafting also showed significant differences which might be due to congenial environmental condition prevailing during post grafting hardening period which coincided with monsoon rains under Periyakulam conditions. These findings were similar with the Manga et al., (2017) in guava, Prajapati et al., (2014) in Mango, Mulla et al., (2005) in Jamun and Giri \& Lenka (2008) in Wood apple.

\section{Effect of method and time of propagation on chlorophyll content of leaves (mg/g)}

Among different methods and time of propagation, maximum chlorophyll content was observed in the softwood grafting done on $15^{\text {th }}$ August $(0.80 \mathrm{mg} / \mathrm{g})$ which is on par with $15^{\text {th }}$ July $(0.75 \mathrm{mg} / \mathrm{g})$ followed by Hardwood cuttings of $15^{\text {th }}$ August $(0.74 \mathrm{mg} / \mathrm{g})$. The leaf chlorophyll content directly influences the photosynthesis which increases the size of the leaves. The significant differences in leaf chlorophyll content in the present study before the time of propagation might be due to the increase in the photosynthetic efficiency of leaves and the results are in agreement with Chandan et al., (2006).

From this study, the results were concluded that manila tamarind propagated through softwood grafting on $15^{\text {th }}$ July showed the significant influence on various growth parameters. In addition, the same technique also observed the highest success percentage and survival rate. Hence the findings through this investigation is highly suitable for commercial propagation of manila tamarind.

\section{References}

Angadi, S. G., and Rajeshwari, K. (2012). Standardization of Softwood Grafting Technique in Jamun under poly mist house conditions. Mysore Journal of Agricultural Sciences, 46(2), 429-432.

Chandan, P. M., Kadam, J. H., and Ambad, S. N. (2006). Effect of different polyembryonic and monoembryonic rootstocks on performance of Dashehari mango. Int. J. Agric. Sci, 2(2), 594-595.

Chovatia, R. S., and Singh, S. P. (2000). Effect of time on budding and grafting success in jamun (Syzygium cumini Skeel). Indian Journal of Horticulture, 57(3), 255-258.

Dhar, M. (1998). Techniques of vegetative and in vitro propagation of jackfruit. Institute of Postgraduate Studies in Agriculture, Salna, Gazipur, Bangladesh.

Giri, B., and Lenka, P. C. (2008). Studies on vegetative propagation of wood apple. Orissa J. Hort, 36(1), 124-125.

Gurjar, P. S., \&Singh, R. (2012). Performance of wedge grafting in aonla at poly house and open field conditions. Environment and Ecology, 30(3), 531-536.

Hartmann, H. T., and Kester, D. E. (1975). Plant propagation: principles and practices. Plant propagation: principles and practices. $3 r d$ edition.

Karna, A. K., Varu, D. K., Panda, P. A., and Hota, D. (2017). Standardization of grafting time and height on success of softwood grafting in mango (Mangifera indica L.). J. Pharmacogn. Phytochem, 6(5), 2803-7.

Kaur, A., and Kaur, A. (2019). Effect of propagation time and methods on the success rate of grafted mango $\mathrm{CV}$. amrapali. Agricultural Research Journal, 56(4), 644-650.

Lal, N., and Nath, V. (2017). SWEET TAMARIND.

Little Jr, E. L. (1983). Common fuelwood crops. Morgantown, WV: CommuniTech. Associates, 34.

Madalageri, M. B., Sulikeri, G. S., Hulamani, 
N. C., and Patil, V. S. (1990). Studies on green wood wedge grafting in sapota. Indian Journal of Horticulture, 41, 69-72.

Manga, B., Jholgiker, P., Swamy, G. S. K., Prabhuling, G., and Sandhyarani, N. (2017). Standardization of Optimum Season for Softwood Grafting in Guava (Psidium guajava L.) cv. Sardar. Int. J. Curr. Microbiol. App. Sci, 6(5), 28142818.

Mulla, B. R., Angadi, S. G., Karadi, R., Patil, V. S., Mathad, J. C., and Mummigatti, U. V. (2011). Studies on softwood grafting in jamun (Syzygium cumini Skeels.). Acta horticulturae, (890), 117.

Nachegowda, N., and Vasanth, K. R. (1996). Propagation of sapota (Manilkera achras (Mill) Foseberg) cv. Kalipatti by softwood grafting. In Proc. Int. Conf. Ttropical Grafts (pp. 115-119).

Pampanna Y, Sulikeri GS, Hulamani NC. Effect of season on the success of softwood grafting in sapota (cv. Kalipatti), South Indian Horticulture. 2000; 42:303-308.

Panse, V. G., and Sukhatme, P. V. (1954). Statistical methods for agricultural workers. Statistical methods for agricultural workers.

Prajapati, G. K., Patel, M. M., Bhadauria, H. S., Varma, L. R., Modi, D. J., and Garasiya, V. R. (2014). Study of softwood grafting on different mango varieties. Asian $J$. Hort, 9(1), 240-242.

Rani, S., Sharma, A., Wali, V. K., Bakshi, P., and Ahmed, S. (2015). The standardization of method and time of propagation in guava (Psidium guajava). Indian Journal of Agricultural Sciences, 85(9), 1162-9.

Reddy, M. L. N., Sivudu, B. V., Baburatan, P., and Dorajeerao, A. V. D. (2014). Effect of structural conditions on veneer grafting success and survival of mango grafts (Mangifera indica cv. Banganpalli). Plant Arch, 14, 71-75.

Rymbai, H., and Reddy, G. S. (2010). Effect of IBA, time of layering and rooting media on air-layers and plantlets survival under different growing nursery conditions in guava. Indian Journal of Horticulture, 67(4), 99-104.

Sanjay, S., Sengupta, B. N., and Singh, S. (1996). Effect of time on soft wood grafting in mango cv. Amrapali. Horticultural Journal, 9(1), 13-16.

Shanker S. 1999. Practical manual in horticulture. Balyog Prakashan, p 41.

Swamy, K. R. M., Singh, R., and Mohan, E. (1990). Correlation of success in softwood grafting cashew with weather parameters. South Indian Horticulture, 38(6), 297300.

Ullah S S, Malik S, Prakash S and Singh M K 2017. Standardization of time and techniques of grafting for quality production of nursery plants of Amrapali mango (Mangifera indica L.) J Pharmacog Phytochem 6: 14-17.

Usare, E. (2016). Study on effect of time of grafting and different grafting methods on propagation of mango (Doctoral dissertation, Indira Gandhi Krishi Vishwavidyalaya, Raipur).

Valsalskumari, P. K, and Jose, M. (1991). Standardization of epicotyl and softwood grafting in jackfruit. South Indian Hort, 39(5), 264-267.

Visen, A., Singh, J. N., and Singh, S. P. (2010). Standardization of wedge grafting in guava under North Indian plains. Indian Journal of Horticulture, 67(4), 111-114.

\section{How to cite this article:}

Keerthika, R., J. Rajangam, T. Arumugam and Venkatesan, K. 2020. Standardization of Propagation Techniques in Manila Tamarind (Pithecellobium dulce (Roxb.) Benth.) var. PKM 1. Int.J.Curr.Microbiol.App.Sci. 9(11): 269-277. doi: https://doi.org/10.20546/ijcmas.2020.911.032 